\title{
Purification and Partial Characterization of Multiple Bromoperoxidases from Streptomyces griseus
}

\author{
By RALF ZEINER, KARL-HEINZ VAN PEE AND FRANZ LINGENS* \\ Institut fur Mikrobiologie der Universität Hohenheim, Garbenstr. 30, D-7000 Stuttgart 70, FRG
}

(Received 22 Jamuary 1988; revised 29 July 1988)

\begin{abstract}
The presence of multiple bromoperoxidases in extracts of Streptomyces griseus Tu 6 was detected. The enzyme pattern varied with the age of the culture. A haem-type bromoperoxidase (BPO 2) was always present. Additionally three nonhacm-type bromoperoxidases (BPO 1a, $1 \mathrm{~b}$ and 3) were detected and purified to homogeneity. The $M_{\mathrm{r}}$ of non-denatured BPO 1a was $70000 \pm 10000$ and those of BPO $1 \mathrm{~b}$ and 3 were $90000 \pm 5000$. BPO $1 \mathrm{a}$ and $1 \mathrm{~b}$ were dimers with subunit $M_{\mathrm{r}}$ values of 34000 and 43000 , respectively. BPO 3 was a trimer with a subunit $M_{\mathrm{r}}$ of 31000. The enzymes differed in their isoelectric points, heat stability, and $K_{m}$ values. In immunodiffusion experiments BPO $1 \mathrm{a}$ and 3 showed partial identity with the nonhaem-type bromoperoxidase from Streptomyces aureofaciens. The nonhaem-type BPO 1a, 1b and 3 had neither peroxidase nor catalase activity.
\end{abstract}

\section{INTRODUCTION}

Halogenated organic compounds are recognized to pose a problem to the environment, because they are often toxic and can not be degraded casily (Müller \& Lingens, 1986). The production of halogenated compounds by chemical halogenation usually results in the formation of halogenated byproducts, because chemical halogenation is not very specific. Thus halogenating enzymes, which should be capable of very specific halogenation reactions, have attracted increasing attention during the last few years.

Halogenating enzymes, the so called haloperoxidases, are produced by different organisms, such as mammals (Dumontet \& Rousset, 1983; Olsen \& Little, 1984), invertebrates (Ahern et al., 1980; Deits et al., 1984), algae (Hewson \& Hager, 1980; Baden \& Corbett, 1980; De Boer et al., 1986 a, b), fungi (Morris \& Hager, 1966; Liu et al., 1987) and bacteria (Wiesner et al., 1985). The large majority of the haloperoxidases isolated from these organisms are haem-type haloperoxidases with protoporphyrin IX as the prosthetic group. These haem-type haloperoxidases are inactivated during incubation with $\mathrm{H}_{2} \mathrm{O}_{2}$ (Liu et al., 1987). As these enzymes also have peroxidase activity, oxidation products are formed in addition to the halogenated products (Corbett et al., 1980). However, nonhaem-type haloperoxidases, which have been isolated from algae (De Boer et al., 1986a, b; Itoh et al., 1985), from a fungus (Liu et al., 1987) and from bacteria (Wiesner et al., 1986; van P'e et al., 1987), have very little or no peroxidase activity and are much more stable under reaction conditions (Liu et al., 1987; Itoh et al., 1987).

Most of the halogenating enzymes so far isolated are bromoperoxidases. Only two nonhaemtype chloroperoxidases have been isolated (Wiesner et al., 1986; Liu et al., 1987). Although the bacteria from which haloperoxidases have been isolated (van PGe \& Lingens, 1985 a, b; Wiesner et al., 1985; van P'e et al., 1987) produce chlorinated metabolites, only bromoperoxidases could be isolated from these strains, with the exception of Pseudomonas pyrrocinia. This bacterium has a nonhaem-type chloroperoxidase and a haem-type bromoperoxidase (Wiesner et al., 1986), whereas Streptomyces aureofaciens produces a nonhaem-type and a haem-type bromoperoxidase (van Pbe et al., 1987).

Abbreviations: BPO, bromoperoxidase; PMSF, phenylmethylsulphonyl fluoride. 
The two nonhaem-type bacterial haloperoxidases differ in many respects from the eukaryotic enzymes. To get more information about bacterial halogenation, we screened various Streptomyces strains, known to produce halogenated metabolites, for halogenating enzymes. In Streptomyces griseus Tü 6, which produces 6,3'-dichlorogenistein (König et al., 1977), we detected one haem-type and three nonhaem-type haloperoxidases. This was the first time that halogenating activity had been detected in crude extracts of bacteria, and also the first demonstration of multiple forms of prokaryotic haloperoxidases. Multiple forms of plant peroxidases are well known (Shannon et al., 1966; Kay \& Basile, 1987), but in the case of haloperoxidases only the fungal haem-type chloroperoxidase from Caldariomyces fumago (Sae \& Cunningham, 1979; Pickard \& Hashimoto, 1982; Hashimoto \& Pickard, 1984) and the ligninase-bromoperoxidase (Renganathan et al., 1987) from Phanerochaete chrysosporium (Leisola et al., 1987), are known to produce multiple forms. Although Kenigsberg et al. (1987) demonstrated that the multiple forms of chloroperoxidase in $C$. fumago are due to posttranslational modifications and are thus not real isoenzymes, little is known about the properties of these multiple forms.

Here we describe the purification and some properties of multiple forms of nonhaem-type bromoperoxidases from Streptomyces griseus Tü 6.

\section{METHODS}

Reagents. Hydrogen peroxide ( $30 \%, \mathrm{v} / \mathrm{v})$ was purchased from Merck; monochlorodimedone was prepared from dimedone by chlorination with sodium hypochlorite (Hager et al., 1966); o-dianisidine (3,3'-dimethoxybenzidine) was from Sigma.

Organism and culture conditions. Streptomyces griseus Tü 6 was kindly supplied by Professor H. Zähner, University of Tübingen, FRG. The growth medium contained $2 \%(w / v)$ soybean flour and $2 \%(w / v)$ mannitol. The strain was grown in 1 litre Erlenmeyer flasks, containing 0.1 litre of medium, at $30^{\circ} \mathrm{C}$ on a rotary shaker. Cultures were harvested by centrifugation, yielding about $10 \mathrm{~g}$ (wet wt) $\mathrm{l}^{-1}$.

Enzyme assays. Halogenating activity was measured according to the method of Hewson \& Hager (1980) with monochlorodimedone ( $44 \mu \mathrm{M})$ as substrate in the presence of $\mathrm{H}_{2} \mathrm{O}_{2}(7.2 \mathrm{mM})$ and bromide $(82 \mathrm{mM})$ and a suitable amount of enzyme in $0.1 \mathrm{M}$-sodium acetate buffer (pH 5.5). The reaction was started by the addition of enzyme. The decrease in monochlorodimedone absorbance at $290 \mathrm{~nm}\left(\varepsilon=1.99 \times 10^{4} \mathrm{M}^{-1} \mathrm{~cm}^{-1}\right)$ with time was recorded. One unit ( $1 \mathrm{U}$ ) of bromoperoxidase activity was defined as the formation of $1 \mu \mathrm{mol}$ monobromomonochlorodimedone $\min ^{-1}$. The brominating activity at different temperatures was measured by preincubating the assay mixture without $\mathrm{H}_{2} \mathrm{O}_{2}$ and enzyme at the given temperature. The reaction was started by the addition of enzyme immediately after the addition of $\mathrm{H}_{2} \mathrm{O}_{2}$. The activity was measured against a blank containing the same components except enzyme.

Peroxidase activity was assayed as described by Claiborne \& Fridovich (1979) with o-dianisidine (48 $\mu \mathrm{M})$ as the substrate in the presence of $7.2 \mathrm{mM}-\mathrm{H}_{2} \mathrm{O}_{2}$ in $0.1 \mathrm{M}$-sodium acetate buffer (pH 5.5). The oxidation of $o$-dianisidine was followed at $460 \mathrm{~nm}$. Catalase activity was measured photometrically at $240 \mathrm{~nm}$ according to Claiborne \& Fridovich (1979).

Separation and purification of the multiple bromoperoxidases. All steps were performed at $4^{\circ} \mathrm{C}$. The crude extracts were prepared by suspending one part $(500 \mathrm{~g}$ wet wt) of cells in two parts of $500 \mathrm{~mm}$-ammonium acetate buffer (pH 6.8) and disrupting the cells with a Branson sonifier J 17-A for twenty 30 s periods. The cell debris was removed by centrifugation for $30 \mathrm{~min}$ at $22100 \mathrm{~g}$. The precipitate was resuspended in one volume of buffer and disrupted as before. Finally the extracts were combined and ammonium sulphate was added to $40 \%$ saturation. After stirring for $30 \mathrm{~min}$, the precipitate was removed by centrifugation and discarded. Ammonium sulphate was added to the supernatant solution to $90 \%$ saturation and stirred for $30 \mathrm{~min}$. The precipitate was collected by centrifugation, redissolved in 100 mM-ammonium acetate buffer (pH 6.8) and dialysed against 10 mM-ammonium acetate buffer ( $\mathrm{pH} \mathrm{6.8)} \mathrm{for} 15 \mathrm{~h}$. After centrifugation, the dialysed proteins were adsorbed onto a DEAE-cellulose DE 52 column $(5.6 \times 8 \mathrm{~cm}$ ), equilibrated with 50 mu-ammonium acetate buffer (pH 6.8). The sample was washed onto the column with 2 litres of this buffer, containing $0.1 \mathrm{M}-\mathrm{KCl}$, and eluted with a linear $600 \mathrm{ml}$ gradient of $0 \cdot 1$ $0.7 \mathrm{M}-\mathrm{KCl}$ in $50 \mathrm{~mm}$-ammonium acetate buffer (pH 6.8). Fractions (about $4 \mathrm{ml}$ ) were assayed for protein $\left(A_{280}\right)$ and bromoperoxidase activity. Fractions containing brominating activity were pooled and dialysed against 10 mu-potassium phosphate buffer (pH 8.0). As several bromoperoxidase activities were detectable after cultivation in Erlenmeyer flasks, these were labelled according to their elution volume: BPO 1, 2 and 3. BPO 1 and 3 were further purified by heat treatment at $60^{\circ} \mathrm{C}$ for $15 \mathrm{~min}$. After cooling the samples on ice and centrifugation, the precipitates were discarded and the supernatants were adsorbed on a Sepharose $Q$ Fast Flow column $(2.5 \times 10 \mathrm{~cm})$, equilibrated with $50 \mathrm{~mm}$-potassium phosphate buffer $(\mathrm{pH} 8.0)$. BPO 1 was washed onto the column 
with 1 litre of the same buffer, whereas BPO 3 was washed onto the column with $0.2 \mathrm{M}-\mathrm{KCl}$ in $50 \mathrm{mM}$-potassium phosphate buffer (pH 8.0). BPO 1 was eluted with a $600 \mathrm{ml}$ gradient of $0-0.5 \mathrm{M}-\mathrm{KCl}$ in $50 \mathrm{~mm}$-potassium phosphate buffer (pH 8.0) and BPO 3 was eluted with a $600 \mathrm{ml}$ gradient of $0.2-0.7 \mathrm{M}-\mathrm{KCl}$ in 50 mu-potassium phosphate buffer (pH 8-0). Fractions were assayed for protein $\left(\boldsymbol{A}_{280}\right)$ and brominating activity. Pooled active fractions were dialysed against 5 litres of 10 mM-sodium acetate buffer (pH 5.5).

The samples were then applied to a Sepharose Q Fast Flow column $(2.5 \times 10 \mathrm{~cm})$ equilibrated with $50 \mathrm{~mm}$ sodium acetate buffer (pH 5.5) and washed onto this column with $600 \mathrm{ml}$ buffer. Brominating activity was eluted with a linear gradient of $0-0.5 \mathrm{M}-\mathrm{NaCl}$ in $50 \mathrm{~mm}$-sodium acetate buffer (pH 5.5). The pooled active fractions were dialysed against $10 \mathrm{mM}$-ammonium acetate buffer ( $\mathrm{pH}$ 6.8) and concentrated using an Amicon concentrator with a PM 10 membrane. The samples were then applied to a Sephadex G-200 column $(2.6 \times 100 \mathrm{~cm})$, equilibrated with 100 mM-sodium acetate bufier (pH 6.8).

The pooled active fractions of BPO 1 were dialysed against $5 \mathrm{~mm}$-potassium phosphate buffer (pH 7.0) and applied to a Bio-Gel HTP hydroxylapatite column $(2.5 \times 10 \mathrm{~cm})$, equilibrated with $5 \mathrm{mM}$-potassium phosphate buffer. The column was washed with $500 \mathrm{ml}$ of this buffer and eluted with a $400 \mathrm{ml}$ gradient of 5-50 mu-potassium phosphate buffer (pH 7.0). The fractions were assayed for protein $\left(A_{280}\right)$ and brominating activity. Active fractions were pooled and dialysed against 5 litres of $5 \mathrm{mM}$-ammonium acetate buffer (pH 6.8) and concentrated using an Amicon concentrator with a PM 10 membrane.

BPO 3 was passed through a Superose 12 Prep Grade column (HR 16/50) using the Pharmacia FPLC system and $100 \mathrm{mu}$-ammonium acetate buffer (pH 6.8). The most active fractions were pooled, dialysed and concentrated as described for BPO 1.

Analysis of the purified bromoperoxidases by PAGE. A Speed Vac concentrator was used to bring the purified enzymes to a final protein concentration of about $2 \mathrm{mg} \mathrm{ml}^{-1}$. Analytical PAGE under non-denaturing conditions was done in horizontal 7.5\% (w/v) polyacrylamide gels (Fehrnström \& Moberg, 1977) with an LKB 2177 Multiphor system. SDS-PAGE was done by the method of Laemmii (1970).

Analytical isoelectric focusing. This was done in thin-layer plates of $5 \%(w / v)$ polyacrylamide containing a $2.4 \%$ (w/v) solution of ampholines in the pH range 3.5-9.5. An LKB Multiphor system was used according to the manufacturers' instructions (Winter \& Andersson, 1977). Isoelectric points were determined using the IEF calibration kit from Pharmacia (pH range 3.0-10.5).

Gel staining. Gels were stained for protein with Coomassie Brilliant Blue R250, for peroxidase activity with o-dianisidine, for haem iron with benzidine and for protein-bound carbohydrates with Schiff reagent, according to the methods of Barritault et al. (1976), Shannon et al. (1966), Clarke (1964) and Segrest \& Jackson (1972), respectively.

Determination of $M_{\mathrm{r}}$. To estimate the $M_{\mathrm{r}}$ values of the native bromoperoxidases, gel filtration experiments were done with the homogeneous enzymes. The comparative studies were performed with Sephadex G-200 $(2.5 \times 100 \mathrm{~cm})$, Sephacryl S-200 HR $(2.5 \times 200 \mathrm{~cm})$, analytical Superose 12 (HR 10/30) and Superose 12 Prep Grade (HR 16/50).

Effect of proteases on bromoperoxidase activity. Immediately after disrupting the cells, the protease inhibitors PMSF and EDTA were added to the crude extract. With other samples this was done 1, 2 or $3 \mathrm{~d}$ after the preparation of the crude extracts. These were stored at room temperature in the presence of $0.05 \%$ sodium azide. The elution profiles after ion-exchange chromatography on Mono Q at pH 6.8 using the FPLC system were compared and the protein pattern and halogenating activities examined.

Immunological assays. In the Ouchterlony gel diffusion test (London et al., 1971), the BPO 1a and 3 from $S$. griseus were tested with an antiserum raised against the nonhaem-type bromoperoxidase from Streptomyces aureofaciens (van Pée et al., 1987).

Halogenation of pyrrolnitrin. Pyrrolnitrin was brominated as described by van Pée \& Lingens (1984). For the chlorination of pyrrolnitrin, $0.1 \mathrm{M}$-sodium acetate buffer ( $\mathrm{pH} \mathrm{4.0)}$ and a chloride concentration of $8.2 \mathrm{mM}$ were used, as described by Wiesner et al. (1986) for the chlorination of indole. The nonhaem-type BPO 1a and 3 were used for these reactions. The reaction mixture was analysed by GC-MS as described earlier (van Pie \& Lingens, 1984).

\section{RESULTS}

Enzyme pattern. After growth of S. griseus Tü 6 in Erlenmeyer flasks for $80 \mathrm{~h}$, two nonhaemtype bromoperoxidases (BPO 1 and BPO 3) were detected after ion-exchange chromatography (Fig. 1). BPO 3 was the major nonhaem-type haloperoxidase present under these conditions. In addition to BPO 1 and BPO 3, a haem-type bromoperoxidase (BPO 2) was produced. This enzyme also had peroxidase and catalase activity. When cultivation was continued, the pattern of these enzymes changed. After $96 \mathrm{~h}$ BPO 3 activity had decreased to less than one-tenth of the 

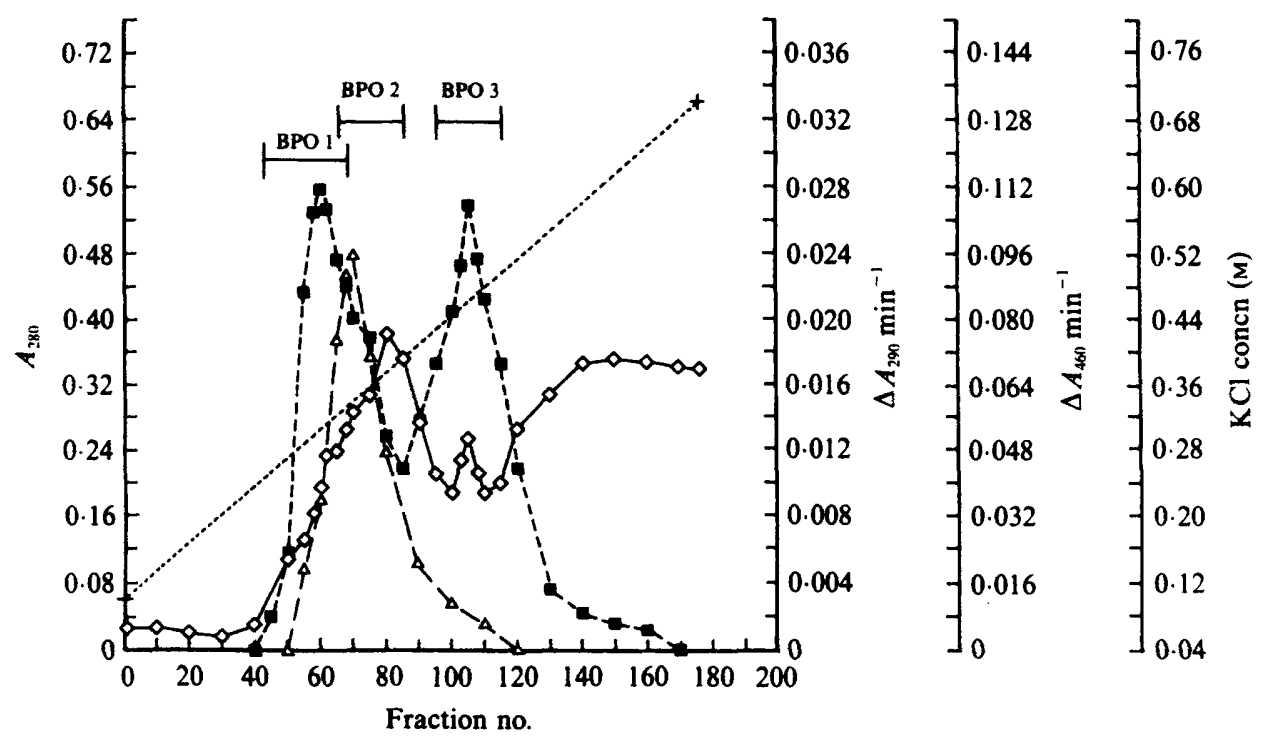

Fig. 1. Elution profile from ion-exchange chromatography on DEAE-cellulose DE 52 (pH 6.8). $\diamond-\diamond$, Protein; $\triangle--\triangle$, peroxidase activity; $\square--\mathrm{n}$, haloperoxidase activity;..,$-- \mathrm{KCl}$ gradient. This pattern was obtained from an $80 \mathrm{~h}$ culture.

activity obtained with cells grown for $80 \mathrm{~h}$, and BPO 1 had become the major nonhaem-type haloperoxidase. The amount of the haem-type BPO 2 did not change significantly.

Effect of proteases on the protein pattern. The overall elution profiles obtained by ion-exchange chromatography of extracts treated with protease inhibitors and of untreated extracts were very different (Fig. 2). However, the pattern of the two nonhaem-type bromoperoxidases BPO 1 and 3 did not change significantly. In extracts without inhibitors $85 \%$ of the activity of BPO 3 remained after $3 \mathrm{~d}$. The activity of BPO 1 did not change at all.

Enzyme purification. The nonhaem-type BPO 1 was purified from cultures grown for $96 \mathrm{~h}$. In the extracts obtained from these cultures, the haem-tye BPO 2 was also present. However, as BPO 2 also had peroxidase activity and could be inactivated by the addition of $\mathrm{NaN}_{3}$, it was possible to distinguish between the enzymes. BPO 1 could be separated into BPO la and BPO 1 b by chromatography on hydroxylapatite (Table 1). BPO 2 was inactivated and separated from BPO la and $1 \mathrm{~b}$ by heat treatment, as BPO 2 was not stable above $40^{\circ} \mathrm{C}$. As the total activity of BPO 3 decreased during prolonged growth, this enzyme was purified from cultures grown for $80 \mathrm{~h}$. The crude extracts also contained the haem-type BPO 2, which could be separated from BPO 3 by heat treatment at $60^{\circ} \mathrm{C}$.

Homogeneity and $\boldsymbol{M}_{\mathrm{r}}$ determination of the subunits. Each of the purified nonhaem-type bromoperoxidases, BPO la, $1 \mathrm{~b}$ and 3, showed a single band on PAGE under non-denaturing and denaturing conditions. The $M_{\mathrm{r}}$ values of the native enzymes were estimated to be $90000 \pm 5000$ (BPO $1 \mathrm{~b}$ and BPO 3) and $70000 \pm 10000$ (BPO $1 \mathrm{a}$ ). BPO $1 \mathrm{a}$ and $1 \mathrm{~b}$ were dimers with subunit $M_{\mathrm{r}}$ values of 34000 and 43000, respectively, whereas BPO 3 was a trimer with a subunit $M_{\mathrm{r}}$ of 31000 . The isoelectric points were estimated to be 4.7, 4.6 and 3.6 for BPO $1 \mathrm{a}, 1 \mathrm{~b}$ and 3, respectively. Only BPO 2 gave positive reactions when stained for peroxidase activity, haem iron, and protein-bound carbohydrate after native PAGE.

Temperature and pH characteristics. Under our assay conditions, BPO la exhibited its highest activity at $40^{\circ} \mathrm{C}$, while BPO 3 was most active at $60^{\circ} \mathrm{C}$. The thermal stability of the bromoperoxidases was different, too: BPO la was totally inactivated after treatment at $60^{\circ} \mathrm{C}$ 

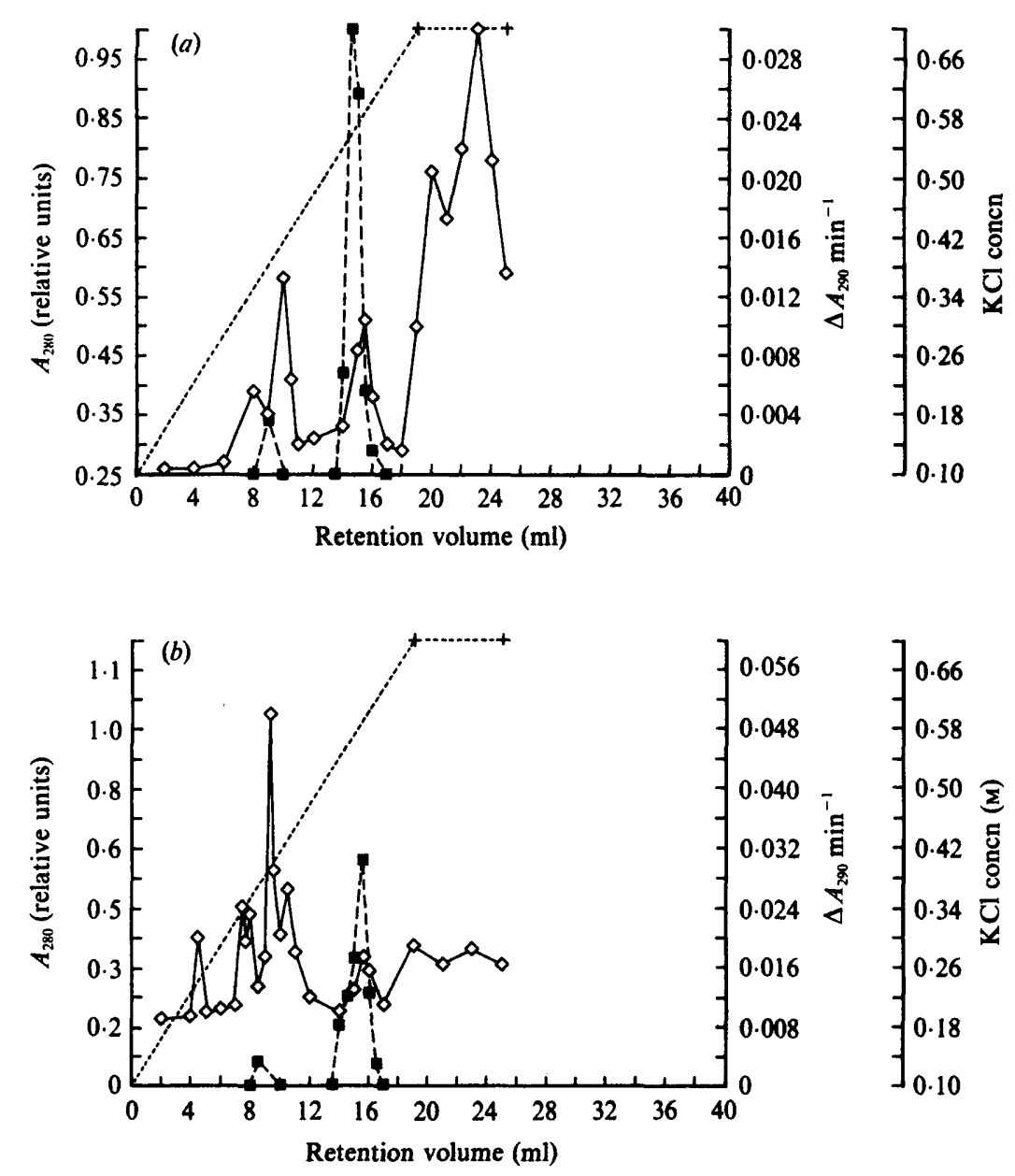

Fig. 2. Influence of protease inhibitors on elution profiles from ion-exchange chromatography on FPLC with Mono Q (pH 6.8). $\diamond-\diamond$, Protein; $\square--\square$, haloperoxidase activity; -.--, KCl gradient. Pattern (a) was obtained from an $80 \mathrm{~h}$ culture, when PMSF and EDTA were added immediately after disrupting. Adding these inhibitors $3 \mathrm{~d}$ after cell disruption yielded the pattern shown in (b).

for 50 min, while BPO $1 \mathrm{~b}$ did not lose any activity under these conditions and BPO 3 retained $60 \%$ of its original activity.

The relative activity of the bromination of monochlorodimedone by BPO la and 3 was plotted against $\mathrm{pH}$ for different concentrations of $\mathrm{H}_{2} \mathrm{O}_{2}(1.6-54.6 \mathrm{mM})$, and $\mathrm{Br}^{-}(18-450 \mathrm{mM})$. BPO 1a showed a pH optimum of 4.5 under all conditions tested. BPO 3 also showed maximum activity at $\mathrm{pH} 4.5$, except that with a low concentration of $\mathrm{H}_{2} \mathrm{O}_{2}(1.6 \mathrm{mM})$ the $\mathrm{pH}$ optimum shifted from $4 \cdot 5$ to $4 \cdot 0$.

Kinetic properties. The $\boldsymbol{K}_{\mathrm{m}}$ values of BPO 1a and 3 were calculated for the three substrates $\mathrm{H}_{2} \mathrm{O}_{2}, \mathrm{Br}^{-}$and monochlorodimedone from Lineweaver-Burk and Hanes plots. The apparent $K_{\mathrm{m}}$ values are listed in Table 2.

Reactions catalysed by the bromoperoxidases from $S$. griseus. The four bromoperoxidases detected in $\boldsymbol{S}$. griseus catalysed the bromination of monochlorodimedone in the presence of $\mathrm{H}_{2} \mathrm{O}_{2}$ and $\mathrm{Br}^{-}$. However, none of these enzymes was able to chlorinate or fluorinate this substrate. The nonhaem-type BPO $1 \mathrm{a}, 1 \mathrm{~b}$ and 3 did not show any peroxidase or catalase 
Table 1. Summary of the purification of bromoperoxidases from S. griseus

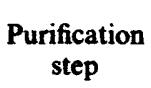

Crude extract

$\left(\mathrm{NH}_{4}\right)_{2} \mathrm{SO}_{4} \mathrm{ppt}$.

DE 52, pH 6.8

Heat treatment

Sepharose Q, pH 8.0

Sepharose Q, pH 5.5

Sephadex G-200

Hydroxylapatite

BPOIb

BPOla

Crude extract

$\left(\mathrm{NH}_{4}\right)_{2} \mathrm{SO}_{4}$ ppt.

DE 52, $\mathrm{pH} 6.8$

Heat treatment

Sepharose Q, pH 8.0

Sepharose Q, pH 5.5

Sephadex G-200

Superose 12

$\begin{array}{cc}\text { Total } & \text { Total } \\ \text { protein } & \text { activity } \\ (\mathrm{mg}) & \text { (U) }\end{array}$

Specific

activity

( $\mathrm{U} \mathrm{mg}^{-1}$ )
Purification Recovery (-fold)
(\%)

BPO 1 (purified from $400 \mathrm{~g}$ bacteria)

\begin{tabular}{ccc}
124822 & 34.8 & 0.003 \\
2628 & 31.5 & 0.012 \\
113.2 & 7.5 & 0.067 \\
78.6 & 7.5 & 0.095 \\
34.0 & 5.3 & 0.155 \\
2.6 & 1.5 & 0.580 \\
0.6 & 1.5 & 2.400 \\
& & \\
0.14 & 0.23 & 1.614 \\
0.20 & 0.56 & 2.800 \\
\multicolumn{1}{c}{ BPO } & 3 (purified from $450 \mathrm{~g}$ bacteria) \\
10418 & 10.3 & 0.001 \\
1341 & 10.7 & 0.008 \\
126 & 2.8 & 0.024 \\
85 & 4.7 & 0.055 \\
5.8 & 2.0 & 0.350 \\
2.2 & 0.9 & 0.400 \\
0.5 & 0.4 & 0.800 \\
0.3 & 0.3 & 1.107
\end{tabular}

0.003

0.067

0.580

$1 \quad 100$

$\begin{array}{rr}4 & 91 \\ 22 & 22 \\ 32 & 22\end{array}$

$32 \quad 22$

$52 \quad 15$

$193-4$

$800 \quad 4$

$538 \quad 0.7$

$933 \quad 1.8$

0

$\begin{array}{rr}1 & 100 \\ 8 & 104 \\ 24 & 27 \\ 55 & 46 \\ 350 & 19 \\ 400 & 9 \\ 800 & 4 \\ 1107 & 3\end{array}$

Table 2. Comparison of BPO la, BPO 1 b and BPO 3 from $S$. griseus with the nonhaem-type bromoperoxidases of $S$. aureofaciens and Corallina pilulifera

\begin{tabular}{|c|c|c|c|c|c|}
\hline \multirow[b]{2}{*}{ Property } & \multicolumn{3}{|c|}{ S. griseus } & \multirow{2}{*}{$\begin{array}{l}\text { S. aureofaciens } \\
\text { Tü } 24^{*}\end{array}$} & \multirow[b]{2}{*}{ C. pilulifera } \\
\hline & BPO la & BPO lb & BPO 3 & & \\
\hline $\begin{array}{l}M_{\mathrm{r}} \\
\text { Subunit } M_{\mathrm{r}} \\
\text { No. of subunits } \\
\text { pI } \\
\text { pH optimum } \\
\left.\text { Sp. act. (U mg } \mathrm{mg}^{-1}\right) \\
K_{\mathrm{m}}\left(\mathrm{H}_{2} \mathrm{O}_{2}\right)(\mathrm{M}) \\
K_{\mathrm{m}}\left(\mathrm{Br}^{-}\right)(\mathrm{M}) \\
K_{\mathrm{m}} \text { (monochloro- }\end{array}$ & $\begin{array}{c}70000 \pm 10000 \\
34000 \\
2 \\
4.6 \\
4.5 \\
1.6 \\
4.3 \times 10^{-2} \\
1.6 \times 10^{-1}\end{array}$ & $\begin{array}{c}90000 \pm 5000 \\
43000 \\
2 \\
4 \cdot 7 \\
- \\
2 \cdot 8 \\
- \\
-\end{array}$ & $\begin{array}{c}90000 \pm 5000 \\
31000 \\
3 \\
3.6 \\
4.5 \\
1 \cdot 1 \\
6.4 \times 10^{-3} \\
9.5 \times 10^{-2}\end{array}$ & $\begin{array}{c}92500 \pm 2500 \\
31000 \\
3 \\
- \\
4 \cdot 5 \\
2.3 \\
3.1 \times 10^{-3} \\
5.9 \times 10^{-2}\end{array}$ & $\begin{array}{c}790000 \\
64000 \\
12 \\
3 \cdot 0 \\
6 \cdot 0 \\
26 \cdot 3 \\
9 \cdot 2 \times 10^{-5} \\
1 \cdot 1 \times 10^{-2}\end{array}$ \\
\hline dimedone) (M) & $7.9 \times 10^{-6}$ & - & $2.0 \times 10^{-6}$ & - & - \\
\hline
\end{tabular}

activities, whereas the haem-type BPO 2 showed these activities in addition to brominating activity.

Pyrrolnitrin was brominated, but not chlorinated, by the nonhaem-type BPO la and 3.

Immunological results. The cross-reactions were performed with antiserum raised against homogeneous nonhaem-type bromoperoxidase from Streptomyces aureofaciens. The immunochemical reactions between this antiserum and BPO $1 \mathrm{a}$ and 3 from $S$. griseus were examined. Both bromoperoxidases produced a spurred precipitin line (Fig. 3). 


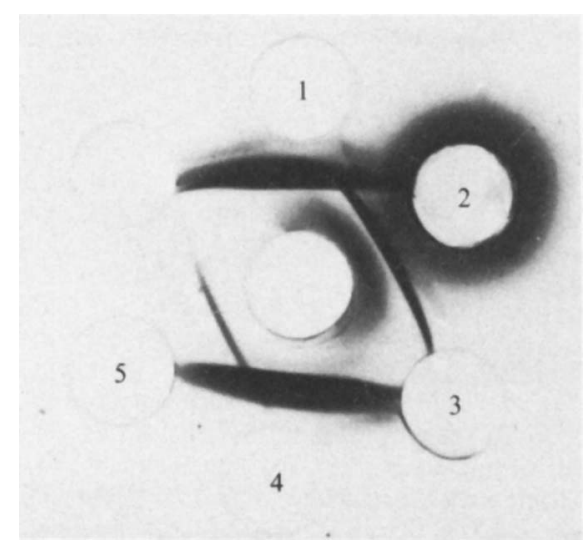

Fig. 3. Ouchterlony gel diffusion test. The central well contained antiserum raised against bromoperoxidase from Streptomyces aureofaciens Tü 24. Wells 1 and 4 contained $S$. aureofaciens Tü 24 bromoperoxidase; well 2 contained BPO 3 from $S$. griseus Tü 6 and well 5 contained BPO la from $S$. griseus Tú 6.

\section{DISCUSSION}

Four different bromoperoxidases were detected in Streptomyces griseus Tü 6. The pattern of these bromoperoxidases varied with the age of the culture. The decrease in total activity of BPO 3 during prolonged growth was not due to its digestion by proteases present in the crude extracts, as these had no effect on the total activity of BPO $1 \mathrm{a}, 1 \mathrm{~b}$ and 3, whereas the overall protein pattern was changed significantly. Thus BPO $1 \mathrm{a}$ and $1 \mathrm{~b}$ are not artefacts, produced by digestion with proteases after preparation of the cell-free extracts. BPO 3 is probably digested in the cells during prolonged growth. The production of haem-type and nonhaem-type haloperoxidases was also detected in Pseudomonas pyrrocinia (Wiesner et al., 1986) and Streptomyces aureofaciens (van Pée et al., 1987); however, no multiple forms of the nonhaemtype haloperoxidases were detected in these strains.

BPO 3 had an $M_{\mathrm{r}}$ of $90000 \pm 5000$ with a subunit $M_{\mathrm{r}}$ of 31000 , and is thus very similar to the nonhaem-type bromoperoxidase from $S$. aureofaciens, which was also reported to be a trimer (van Pée et al., 1987). The other two nonhaem-type bromoperoxidases, BPO la and 1b, were dimers (Table 2).

BPO 1a and 3 were the major nonhaem-type bromoperoxidases present and were thus used for further comparative studies.

The molecular and catalytic properties of the nonhaem-type bromoperoxidases from $S$. griseus were very similar to those of the nonhaem-type bromoperoxidase from $S$. aureofaciens Tü 24 (van Pée et al., 1987), but quite different from the nonhaem-type bromoperoxidase of the red alga Corallina pilulifera (Itoh et al., 1986) (Table 2). BPO la and 3 gave cross-reactions in immunodiffusion experiments with antiserum against $S$. aureofaciens bromoperoxidase; they both showed partial identity. This similarity to the enzyme from $S$. aureofaciens Tü 24 was also confirmed for BPO 3 by partial amino acid sequence analysis of the $\mathrm{NH}_{2}$-terminal end. The sequences differed in only 5 positions out of 15 (data not shown).

Each of the bromoperoxidases purified from $S$. griseus differed from the others with respect to most of the properties examined. It is not clear from these results whether these enzymes are the products of the same or different genes.

None of the bromoperoxidases from $S$. griseus was able to catalyse the chlorination of monochlorodimedone. BPO 1a and 3 catalysed the bromination of the antibiotic pyrrolnitrin, but not its chlorination. It is not yet clear, whether these bromoperoxidases can not catalyse chlorination at all, or whether, as in the case of the nonhaem-type chloroperoxidase from Pseudomonas pyrrocinia, chlorination is much more specific than bromination (Wiesner et al., 1986). 
This investigation was supported by the Bundesministerium für Forschung und Technologie and by the Fonds der Chemischen Industrie.

\section{REFBRENCES}

Akren, T. J., Allan, G. G. \& Mrdcalf, D. G. (1980). New bromoperoxidases of marine origin. Partial purification and characterization. Biochimica et biophysica acta 616, 329-339.

BADEN, D. G. \& CORBETT, M. D. (1980). Bromoperoxidases from Penicillus capitatus, Penicillus lamourouxii and Rhipocephalus phoenix. Biochemical Journal 187, 205-211.

Barritault, D., ExPert-Betaucon, M., Milet, M. \& HAYES, D. H. (1976). Inexpensive and easily built small scale 2D electrophoresis equipment. Analytical Biochemistry 70, 600-611.

Claiborne, A. \& Fridovich, I. (1979). Purification of the o-dianisidine peroxidase from Escherichia coli. Journal of Biological Chemistry 254, 4245-4252.

Clarke, J. T. (1964). Simplified disk (polyacrylamide gel) electrophoresis. Annals of the New York Academy of Sciences 121, 428-436.

Corbett, M. D., Chipro, B. R. \& Batchelor, A. O. (1980). The action of chloride peroxidase on 4chloroaniline. Biochemical Journal 187, 893-903.

De Bozr, E., van Kooyk, Y., Tromp, M. G. M., Plat, H. \& WeVER, R. (1986a). Bromoperoxidase from Ascophyllum nodosum: a novel class of enzymes containing vanadium as a prosthetic group? Biochimica et biophysica acta 869, 48-53.

De Boer, E., Tromp, M. G. M., Plat, H., KrenN, G. E. \& WEVER, R. (1986b). Vanadium (V) as an essential element for haloperoxidase activity in marine brown algae: purification and characterization of a vanadium ( $V$ )-containing bromoperoxidase from Laminaria saccharina. Biochimica et biophysica acta 872, 104-115.

Deits, T., Farrance, M., Kay, E. S., Mednl, L., TURner, E. E., Wriduan, P. J. \& Shapiro, B. M. (1984). Purification and properties of ovoperoxidase, the enzyme responsible for hardening the fertilization membrane of the sea urchin egg. Journal of Biological Chemistry 259, 13525-13533.

Dumontet, C. \& Rousset, B. (1983). Identification, purification, and characterization of a non-heme lactoperoxidase in bovine milk. Journal of Biological Chemistry 258, 14166-14172.

FetrRnstró, H. \& MoBerg, U. (1977). SDS and conventional polyacrylamide gel electrophoresis with LKB 2114 Multiphor. LKB Application Note no. 306, pp. 12-15.

Hager, L. P., Morris, D. R., Brown, F. S. \& Eberwen, H. (1966). Chloroperoxidase. II. Utilization of halogen anions. Journal of Biological Chemistry 241, 1769-1777.

Hastimoto, A. \& Pickard, M. A. (1984). Chloroperoxidases from Caldariomyces (= Leptoxyphium) cultures: glycoproteins with variable carbohydrate content and isoenzymic forms. Joumal of General Microbiology 130, 2051-2058.

Hewson, W. D. \& HAGER, L. P. (1980). Bromoperoxidase and halogenated lipids in marine algae. Journal of Phycology 16, 340-345.

IToH, N., Izuna, Y. \& YaMADA, H. (1985). Purification of bromoperoxidase from Corallina pilulifera. Bio- chemical and Biophysical Research Communications 131, 428-435.

Itoh, N., Cheng, L. Y., Izuma, Y. \& Yamada, H. (1987). Immobilized bromoperoxidase of Corallina pilulifera as a multifunctional halogenating biocatalyst. Journal of Biotechnology 5, 29-38.

KAY, L. E. \& BASILE, D. V. (1987). Specific peroxidase isoenzymes are correlated with organogenesis. Plant Physiology 84, 99-105.

Kenigsberg, P., FAng, G.-H. \& Hager, L. P. (1987). Post-translational modifications of chloroperoxidase from Caldariomyces fumago. Archives of Biochemistry and Biophysics 254, 409-415.

KöNIG, W. A., KRAUSS, C. \& Z̈̈HNER, H. (1977). Stoffwechselprodukte von Mikroorganismen, 6Chlorgenistein und 6,3'-Dichlorgenistein. Helvetica chimica acta 60, 2071-2079.

LARMMLI, U. K. (1970). Cleavage of structural proteins during the assembly of the head of bacteriophage T4. Nature, London 227, 680-685.

Leisola, M. S. A., Kozulic, B., MeussdokRFFer, F. \& FIECHTRR, A. (1987). Homology among multiple extracellular peroxidases from Phanerochaete chrysosporium. Journal of Biological Chemistry 262, 419424.

LIU, T.-N. E., M'Tngulu, T., Geigert, J., Wolf, B.,

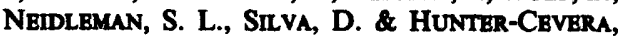
J. C. (1987). Isolation and characterization of a novel nonheme chloroperoxidase. Biochemical and Biophysical Research Communications 142, 329-333.

LONDON, J., MEYER, Y. E. \& KuLCYK, S. R. (1971). Detection of relationship between Streptococcus faecalis and Lactobacillus casei by immunological studies with two forms of malic enzyme. Journal of Bacteriology 108, 196-201.

MorRIS, D. R. \& HAGER, L. P. (1966). Chloroperoxidase. I. Isolation and properties of the crystalline glycoprotein. Journal of Biological Chemistry 2A1, 1763-1768.

MÛ́lLER, R. \& LINGENs, F. (1986). Microbial degradation of halogenated hydrocarbons a biological solution to pollution problems? Angewandte Chemie (International Edition in English) 25, 779-789.

OLsen, R. L. \& LITTLE, C. (1984). Purification and some properties of myeloperoxidase and eosinophil peroxidase from human blood. Biochemical Journal 209, 781-787.

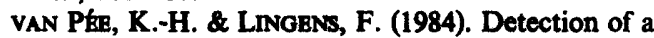
bromoperoxidase in Streptomyces phaeochromogenes. FEBS Letters 173, 5-8.

van PÉ, K.-H. \& LnNGens, F. (1985a). Purification of bromoperoxidase from Pseudomonas aureofaciens. Journal of Bacteriology 161, 1171-1175.

Van Pfez, K.-H. \& Lingens, F. (1985b). Purification and molecular and catalytic properties of bromoperoxidase from Streptomyces phaeochromogenes. Journal of General Microbiology 131, 1911-1916.

van PEB, K.-H., SURY, G. \& Lingens, F. (1987). Purification and properties of a nonheme bromoperoxidase from Streptomyces aureofaciens. Biological Chemistry Hoppe-Seyler 368, 1225-1232. 
Pickard, A. M. \& Hashimoto, A. (1982). Isoenzymes of chloroperoxidase from Caldariomyces fumago. Canadian Journal of Microbiology 28, 1382-1388.

Renganathin, V., Miri, K. \& Gold, M. H. (1987). Haloperoxidase reactions catalyzed by lignin peroxidase, an extracellular enzyme from the basidiomycete Phanerochaete chrysosporium. Biochemistry 26, 5127-5132.

SAE, S. W. \& CUNNINGHaM, B. A. (1979). Isolation and properties of chloroperoxidase isoenzymes. Phytochemistry 18, 1785-1787.

SEGREsT, J. P. \& JACKsoN, R. L. (1972). Glycoprotein staining following electrophoresis on acrylamide gels. Methods in Enzymology 283, 54-63.
Shannon, L. M., Kay, E. \& Lew, Y. (1966). Peroxidase isoenzymes from horseradish roots. Journal of Biological Chemistry 241, 2166-2172.

Wirsner, W., van PÉe, K.-H. \& Lingens, F. (1985). Purification and properties of bromoperoxidase from Pseudomonas pyrrocinia. Biological Chemistry Hoppe Seyler 366, 1085-1091.

WIESNER, W., vaN Pte, K.-H. \& Lingens, F. (1986). Detection of a new chloroperoxidase in Pseudomonas pyrrocinia. FEBS Letters 209, 321-324.

WINTER, A., EK, K. \& ANDERsson, U.-B. (1977). Analytical electrofocusing in thin layers of polyacrylamide gels. LKB Application Note no. 250, pp. 1-9. 